\title{
Low-End Resilience Theory
}

\section{Johannes Birringer}

fter Hurricane Harvey had struck Houston a couple of years ago, homes
were partly destroyed, neighborhoods damaged and livelihoods affected,
the edifices of the theatre district flooded, and for some time, performance operations had to be outsourced. When I returned there in December 2017, the Houston Grand Opera stage crew had just completed building two mobile sets for their repertoire, to be rolled out into the temporary "Resilience Theatre" constructed at Brown Convention Center, a vast Pompidou-like structure commonly used for commercial expositions. The story of the resilient theatre resonated around this city, as a number of arts organizations and cultural venues opened their doors to give refuge to others more afflicted by the natural disaster.

But when the roof leaks, disenchantment sets in. Many damaged homes, just as in New Orleans after Katrina, have not been repaired. So here comes my lowend theory on sanctuaries and resilience, driven by an urge to understand where performance as art and survival kit has drifted during turbulence. Sharing a few observations about the impact of migration and the refugee crisis in Europe, I point also to an absurdist political climate that may not have fully subsumed or choked the arts and performance disciplines. But sanctuaries are scarce, and the ground everywhere I walk seems to be treacherous, as if moving on thin ice. I had already left London, before the Brexit drama went into further convulsions in March 2019, staging a parliamentary crisis of unprecedented, ugly dimensions, at least as long as I can remember England as a safe, relatively sane democratic haven, never mind its forever unresolved class (or racial) divisions and resentments.

One must mind them though. All lives matter, and class resentment (just observe the gilet jaunes in France, the AfD and Neo-Nazis in Germany, the Anders Breivik admirers, the nationalist-populist movements in Eastern Europe or, actually, across all of Europe) is deeply entangled in the racialized religious or secular dark ecology: our era of denials. John Akomfrah, British artist and founding member of the influential Black Audio Film Collective (1982-1998), put his finger into the wound, with film installations such as The Unfinished Conversation (drawing on diaries of the cultural theorist Stuart Hall to explore issues of 
race and ethnicity), Vertigo Sea (about the experience of migrants in the UK, the trans-Atlantic trade and the beginnings of globalization) or his recent six-channel video Purple (2017) at the Barbican Centre. Purple resonated deeply with me due to its enthralling visual and sonic impact, as I watched young and old people, with their backs to us, gazing at landscapes, stretching from the equator to the polar regions, shots of migrating flamingoes and eerie ocean shores dotted with human detritus intermixed with archive material-documentary footage of belching chemical factories, steel workers pouring molten iron or farmers spraying crops. The montage of nature/culture is shocking and heart-rending; we see places that European industrial empires exploited for centuries and the richest nations on earth can ignore. They are also the very places already feeling the deeper effects of climate change.

\section{GHOST TREES}

On the continent, the European attachment to Schengen was surely an economic one, but also a welcome hallucination, a sweet romance of freedom to move across, carved out after two devastating world wars and a bitter ideological divide of cold war conflict, which after the disappearing Wall seemed laid to rest. The former East meeting the former West. It's hard to believe the Wall fell thirty years ago, and that the Soviet bloc vanished. The EastWest is now united by what Slovene philosopher Marina Gržinić scathingly describes as the new necropolitics, a redlining of the expendables, those with bare lives. Recent migration in Europe has led to a crisis about determent politics, disembarkation and management strategies: how to receive both economic migrants and asylum seekers who flee war and human rights abuses (Syria, Iraq, and Afghanistan are the top three countries of origin for asylum seekers in the EU), how to "process" them, how to deal with the social fallout, the increasingly contentious debates on cultural integration, national identity, and liberal democracy, shadowed by innumerable images of the barely sheltered on Greek islands, the huddled masses in "jungle" camps (Calais) holding on by the skin of their teeth before getting bulldozed, the boat people crossing the Mediterranean in search of the sea-washed sunset gates. In their book Necropolitics, Racialization, and Global Capitalism (2014), Gržinić and Šefik Tatlić posit necropolitics as a dominant, albeit obscene, form of politics that sustains contemporary racialization (and thus the current waves of nationalism and xenophobia) as a primal ideology of global capitalism, connecting globalization and its modern narratives directly with colonialism.

Sometimes I think of old Europe as a black box, its internal functioning inscrutable. Black rectangles that can transport refugees instantly from one place to another, as Mohsin Hamid so vividly imagines such "doors" in Exit West, are magical fantasy. Giulio Camillo's memory theatre of the 1550 s sought to look 
inside, as he crossed borders traveling through Europe, then built a small-scale model in Venice of his theatre of knowledge, complete with principles of Pythagorean and hermetic philosophy opening out to the sciences and the methods of ars combinatoria. This was a time when utopists like Camillo still had faith in the divine and in alchemical powers of transformation. Natural scientists studied the outside world, organizing its empirical vistas, most notably in Linnaeus's classifications of life forms (Systema naturae) but also in a wonderful book such as Specimen medico-practico-botanicum (Copenhagen 1720) by Balthasar Johannes Buchwald. Its real botanical specimens, plants and herbs, were pressed onto paper, and lyrically described with brief annotations in several languages, regarding their taxonomy and potential healing power. I was reminded of this when reading Bob Gilbert's Ghost Trees: Nature and People in a London Parish (2018), with botanical observations by a self-described parochialist who looks at the rich natural diversity of plants and weeds in his inner-city parish, noticing that immigrants have taken their plant life with them!

Must we not turn to newer sciences of climate change and chaos? Or of continental drifts, using a geological and paleontological approach to an afflicted naturalism, that of a helpless theatre in the face of late capitalism's Dadaist period of a disastrous anthropocene $?^{1}$ For the latter, old Marx's analysis, say in his Fragments on Machines - pertaining to the evolution of the production of labor and capital, from the division of labor to the increasing integration of machines in labor and ever-increasing automatization of labor-is supplanted by ghastly financial markets and disembodied algorithmic trading across computational infrastructures. Borders, speculative capitalism asks, what borders? All the while, boundaries continue to exist, walls are rebuilt or used as populist election bait. The new discourse of toxicity with its alarmed concern about safety and risk spreads everywhere, across political debates on migration, nationalism, culture, health, economics, ecology, race, gender, and cultural practices that try to capture images and sounds from the hurricanes. But has theatre in Europe shown resilience, among waves of political instability and austerity? How is psychological and political resilience expressed aesthetically? I will briefly address three different production approaches and read them through the context I have evoked above. First, I would suggest that austerity in Europe is connected not only to the relative economic strength or weakness of a region but to the ideological/political narratives that are told by the sedentary, parochialist and nomadic imaginaries.

\section{DIGGING GRAVES FOR WATCHING FOUNDATIONS}

In Zagreb, for example, the Croatian theatre ensemble BADco. has produced a string of conceptually and formally challenging productions (since 2000) that examine historical and political questions regarding precisely this: production, 
the social and economic aspects of artistic labor, the task of productivity, and valorization of artistic work through non-aesthetic spheres of social production. Some of their intriguing conceptual performance works have suggestive titles, such as the Biennale di Venezia installation Responsibility for Things Seen / Tales in Negative Space (2011); their ecological camp Nature Needs to be Reconstructed (2013) at the Sava embankment not far from Zagreb's communal waste landfill Prudinec/Jakuševac; or their subsequent Institutions Need to be Reconstructed (2016), a hybrid assemblage combining a film set, performance and temporary residence placed inside deserted factories or unfinished public buildings, former sites of industrial production that nowadays contain the heterotopic potential of becoming cultural centers.

As BADco. members Goran Sergej Pristaš and Tomislav Medak point out, their constructivist interventions shift artistic work into non-aesthetic spheres of social production, while continuously questioning the position of culture in the social system, looking into new institutional models and the problems of institutionalization of contemporary art practices. ${ }^{2}$ For their projects, BADco. not only relies on their core performance collective-comprising three choreographers/dancers, two dramaturgs and one philosopher-but also on collaborations and a rigorously systematic research of protocols of performing, presenting and observing. In Correcting Rhythm, for example, they created a yearlong observatory of "everyday rhythms" that culminated in a theatre production examining temporal form, in particular "disrupted rhythm" as the precondition for a looping of analytical obsession. Everything is there, in a kind of "rhythmanalysis" (once proposed by Henri Lefebvre) that looks at movement in a totality, in all proportions and in all their respects: the rhythms of the body with the rhythms of the society with the rhythms of the planet, but here perceived as an anguished arrhythmia. Fissures have opened up the nervous system.

Their latest project, the performance installation The Foundation Pit (2018) pushes their resilient search for utopian premises of disruptive art further, stolidly insisting that cultural producers can well contribute to the planning of the future of housing, socialization and exchange, yet also of the immediate interconnection of life expectancy and its realization. BADco.'s performative search rehabilitates the legacy of utopian construction of the twentieth century. Their dramaturgy points up the links between the mega-structures of Vjenceslav Richter (and his 1960s Synthurbanism, Heliopolis), the conceptual meta-structures of American architect Lebbeus Woods, but also the dystopian-satirical writings of Andrei Platonov (his novel The Foundation Pit, from the late 1920s, gave the project its title). Drawing on Platonov's dystopic critique of the dissolution of utopian ideas that have fallen into the hands of ineffective and greedy men, BADco.'s 
subtext is the current crisis of political corruption in the city which had led to a protest initiative (Zagreb je NAS!, meaning: Zagreb is ours!) to bring down the mayor of Zagreb. Through The Foundation Pit, BADco. re-tells the story of protagonists who are building a large tower, a proletarian home envisioned to enable a communal life for all members of the working class. This home symbolizes the bright future of a utopian socialist society (Tatlin's Tower and early socrealist depictions of revolutionary fervor spring to mind), but in the end the workers fail to even pour the foundation of this building, and we are left with an absurdist Kafkaesque parable.

BADco.'s practice as a performance ensemble is not easy to describe. I evoked their conceptual schemes in order to exemplify an artistic method that is, to an extent, associated with Brecht's more scientific thought-laboratory: BADco. interrogates different performance formats that demands thought as another mode of perception or another enactment, leading to new social and constructive relations. Interrupting our normal rhythms and the capitalist aesthetic flow of consumption (immediately reconciling all possible excess or transgression) implies rehearsing glitches and ruptures in the "factory of the body" (Pristaš) within multiplicities of situations or dispositifs for which this theatre looks. ${ }^{3}$ It acts therefore also like a manifesto, stubbornly (what Herbert Blau once called the "impossible theatre") demanding thought that probes contradictions in the infrastructures with which we reconstruct living matter that is not there yet but will have re-appeared again.

\section{RITES OF EXILE}

In my next example I turn to a dance-theatre company in exile, even if this is also a contradiction in terms when one examines one's factory of the body and what it always carries with it. Iraqi Bodies is based in Gothenburg, Sweden, led by artistic director Anmar Taha (with co-director Josephine Gray). They have been recognized for their visually and emotionally gripping performances, such as Unidentified, Vowels, Gerontion, Possessed, and Killing from a Distance. When I met with Taha for a physical workshop, I noted his particularly strong focus on a deep listening to the body, a warming up of extended facial muscles, mouth, tongue, eyes, ears, scalp, beautifully combined with attention to feet, soles, toes. At one point he asked the participants to be still, imagining themselves to be dead. In observing Taha's and Grays's choreography (both also perform), one immediately senses the vibrancy of movement-gestures in their physical theatre compositions, inspired by Artaud and Grotowski but also the absurdist humor of Ionesco and Beckett. I learned that Taha emigrated from Iraq after being shot and wounded, following the invasion and fall of Baghdad and during the increasing sectarian violence in the country. He moved to Sweden where he founded the 
company Iraqi Bodies in 2009. During his studies at the Institute of Fine Arts' Theatre Department in Baghdad, theatre was limited to either its intellectual aspect or rhetoric. Taha said they used their bodies to express ideas (not visual art aspects for that matter). When he started directing, there were hardly any actresses, so men had to present the female roles; bodies were imprisoned under layers and layers of restrictions.

Taha's physical theatre, which on occasion uses Arabic, Swedish and English language but largely relies on a sensory, movement based visual aesthetic, pushes into the darker sides of bodies that needed to be liberated and also had to survive trauma. ${ }^{4}$ This is a predicament shared by generations of artists who grew up in war times, under occupation or the strains of civil conflict or apartheid. To name one's company Iraqi Bodies could be taken as a bold, resilient gesture. It is also a paradoxical one, perhaps a sinister allegory of a post-national, globally exiled, imagined community. The ensemble does not promote anything resembling a national or ethnic identity at all but is international, with varying membership including Swedish, Greek, Syrian, and Dutch performers. But the performance images are intensely constructed, with a visual symbolism that reaches boldly into memories, obsessions, nightmares. Performers often wear ape masks or are veiled with scarves and hijabs; objects such as ropes, blindfolds, coffins, suitcases, boxing gloves abound, creating intimations of violence, torture, degradation, and dread.

When I watched Rite of Exile (2017), I was struck by its overall darkness, the black clothes, sparse lighting, silence and near immobility, interrupted at times with seemingly erratic, compulsive movements. There is a brooding atmosphere of unease and danger. But the dark intensity also has tremendous beauty, and its expressionist style reminds us of other works in the field of contemporary choreography (e.g. Hofesh Shechter, Sidi Larbi Cherkaoui, Rachid Ouramdane, Mette Ingvartsen). Rite of Exile opens with Taha found in the center, lying on the floor with hands behind his back as if tied up, his eyes blindfolded. Upstage we can barely make out a rope, coiled on the floor hanging down vertically from the sky. A dim light spot allows us to see merely the contours of the captured body dressed in black trousers and shirt: a prisoner perhaps? He slowly twists and turns. After a while, we barely notice, a second figure has appeared, completely covered in black hijab, who begins to circle the man in the center, first slowly, then more and more agitatedly. The figure enacts flailing movements, a shivering, jerky dance, breathes more and more heavily, then suddenly freezes, stomps her foot five times and vanishes (black out).

When the lights come on, we only see her back, while the prisoner slowly comes alive, as if resuscitated; lifted up, slowly and painfully he rises to his full height, whispering desperate words we cannot hear. The figure in the hijab has turned 
around, wearing a full mask in the shape of a sheep, an archaic figure of the sacrificial lamb, mythic animal associated with exile and slaughter. She holds her belly, as if pregnant, and as the prisoner now escapes Houdini-like, climbing acrobatically up the rope, higher and higher, escaping to the heavens via some imaginary Jacob's ladder, the woman breaks out into an interminably long wailing suada (underscored with electronic music) in a language I do not understand. The earth seems to move, she quivers and quakes, her panic is palpable and makes me break into a sweat, and I feel a seismic energy flooding the room. While her protestations continue, the prisoner-acrobat has slowly ascended into the heavens. Near the end we barely glimpse him as he performs his astonishing slow-motion aerial pirouettes up on high.

On one hand, what becomes apparent in such theatrical work (comparable to some extent with the extravagant visual stylistics of younger directors such as Dimitris Papaioannou or Milo Rau, who have succeeded the Robert Wilson-Pina Bausch-Peter Brook-Christoph Marthaler generation) is a surrealist-expressionist tendency, precise visual compositions delving onto the macabre and the nightmarish, uninterested in the more fashionable cynical comedies or superficial multimedia and immersive-participatory spectacles that crop up everywhere. Participation is an overvalued aesthetic category, whereas empathy and love, on the other hand, as Romanian theatre artist Aristiţa Albăcan suggested at "Shadows of the Dawn," point to an ethical principle for re-empowerment, to a capacity for ritualized forms of individual or collective memory. In performing a compacted series of movement images of the escaping prisoner, Taha did not presume that performance can heal trauma, nor did his theatre pronounce a political message or take on an activist stance, pretending to shock his audience with scenes of violence and terror, as Oliver Frljić's Naše nasilje I vaše nasilje (Our violence is your violence) attempted to do during the 2016 Wiener Festwochen. ${ }^{5}$ No, his ascent is a quiet dream, a writing on the wall.

I felt in Taha's workshop that he trusts bodies to become lucid, to move through empathetic stillness into a consciousness of cruel nuances, to give account of them as Artaud had imagined it to be necessary (in his first "Letter on Cruelty"). Death is continuous, and a necessity. We are plant, mineral flesh, bone, skin, and water. Death is one fate of the human body. Life is someone's death, Artaud proposes, and I sense that Taha does not want to speak about being a victim (never mentioning Baghdad the entire time we were together, except when he laughed over dinner, when I mentioned I was reading Ahmed Saadawi's hallucinatory novel Frankenstein in Baghdad). But in Rite of Exile he urges us to rise up, to unlock our appetite for life, our railing, noisy dervish-like dance of historicity, moving both through non-verbal forms of memory transmission such as silence to other, much louder and wilder acrobatic transformative capacities. 


\section{TELEPRESENCE AND MIGRATION}

This apprehension of an ethical principle brings me to my last example, in search of theatrical resilience that would be sustainable even if austerity and economic necessities diminish the conditions of production, and psychologically exacerbate people's sense of dis-empowerment. When I mentioned Albăcan's appeal to love, I understood her to be arguing against cynical discourses and policies that exploit hate and fear, as we experience it in the societal drifts towards populism, and nationalist, xenophobic and even fascist tendencies in Europe (not to mention the ghastly homophobic platform that Poland's governing party, Law and Justice, has chosen as a vehicle for its re-election campaign as part of a broader struggle against what Polish nationalists and populists call "European values"). Law and justice against European values? This is a spell-binding absurdity. When I directed a workshop in Bucharest's National Dance Center in June 2018, participants afterwards excitedly invited me to join the Gay Pride parade, and there we were, thousands of us, gathered on the square in front of the University, collectively enjoying a moment of free expression of love and the defense of diversity and tolerance. I also noticed that military police had created a safe cordon around us, checking who was going in and out, presumably to protect our expression (Romanians who consider homosexuality to be a threat to society rallied on the same day, a few blocks away, and I found out that Romania, along with Poland, Slovakia, Bulgaria, Lithuania, and Latvia are among European nations that do not legally recognize same-sex couples).

Realizing the economic disparities that exist among European countries, I was drawn to a project organized by Marina Hanganu, artistic director of "TeleEncounters," a telematic theatre collaboration between the George Ciprian Theatre in Buzău, the Universidad Catolica San Antonio de Murcia-UCAM (Spain), and the Municipality of Lousada (Portugal). There are three directors involved in the trans-European collaboration, and as I recalled quite vividly the early years of networked performance through my own involvement in the transnational dance collective ADaPT (founded in 2000), I became intrigued again by the complex logistical choreography that such mediated performances involve, wondering how smart apps and social media today enhance (or not) communications between actors in distant locations. "Tele-Encounters" started up in September 2017 and will finish in the fall of 2019. For the first part of the project Hanganu developed a telematic play between Romania and Spain called The Planet of Lost Dreams (2018), an ironic title that already cast a shadow on my optimistic love ethic. ${ }^{6}$

With actors working in two sites, Buzău (Romania) and Murcia (Spain), the bilingual verbatim play-based on interviews with Romanian migrants in Spain and left-behind families in Romania (especially children)-was staged using 


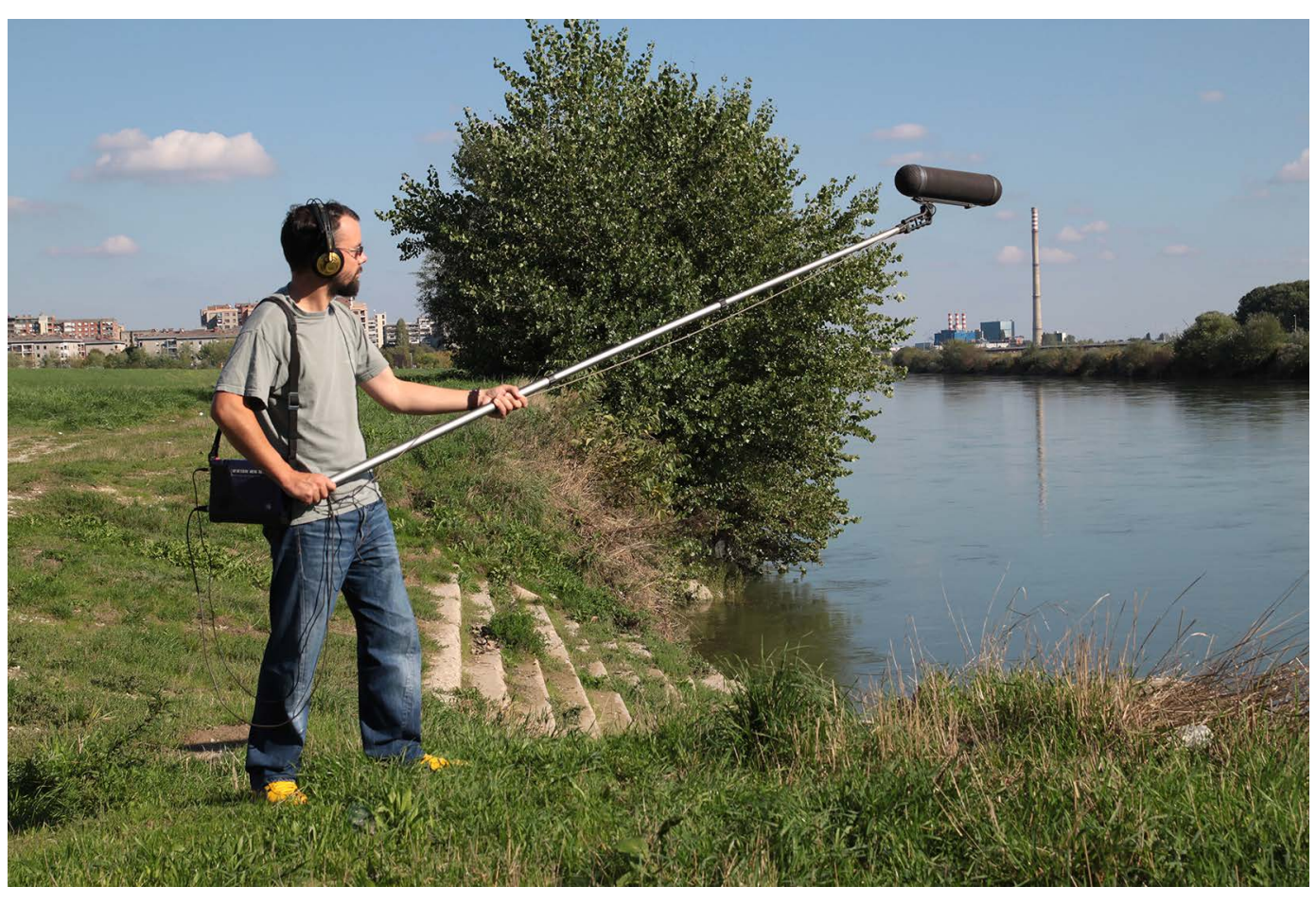

BADco., Nature needs to be reconstructed, artistic-ecological camp at Jakuševac in Zagreb 2013. Photo: Courtesy BADco.

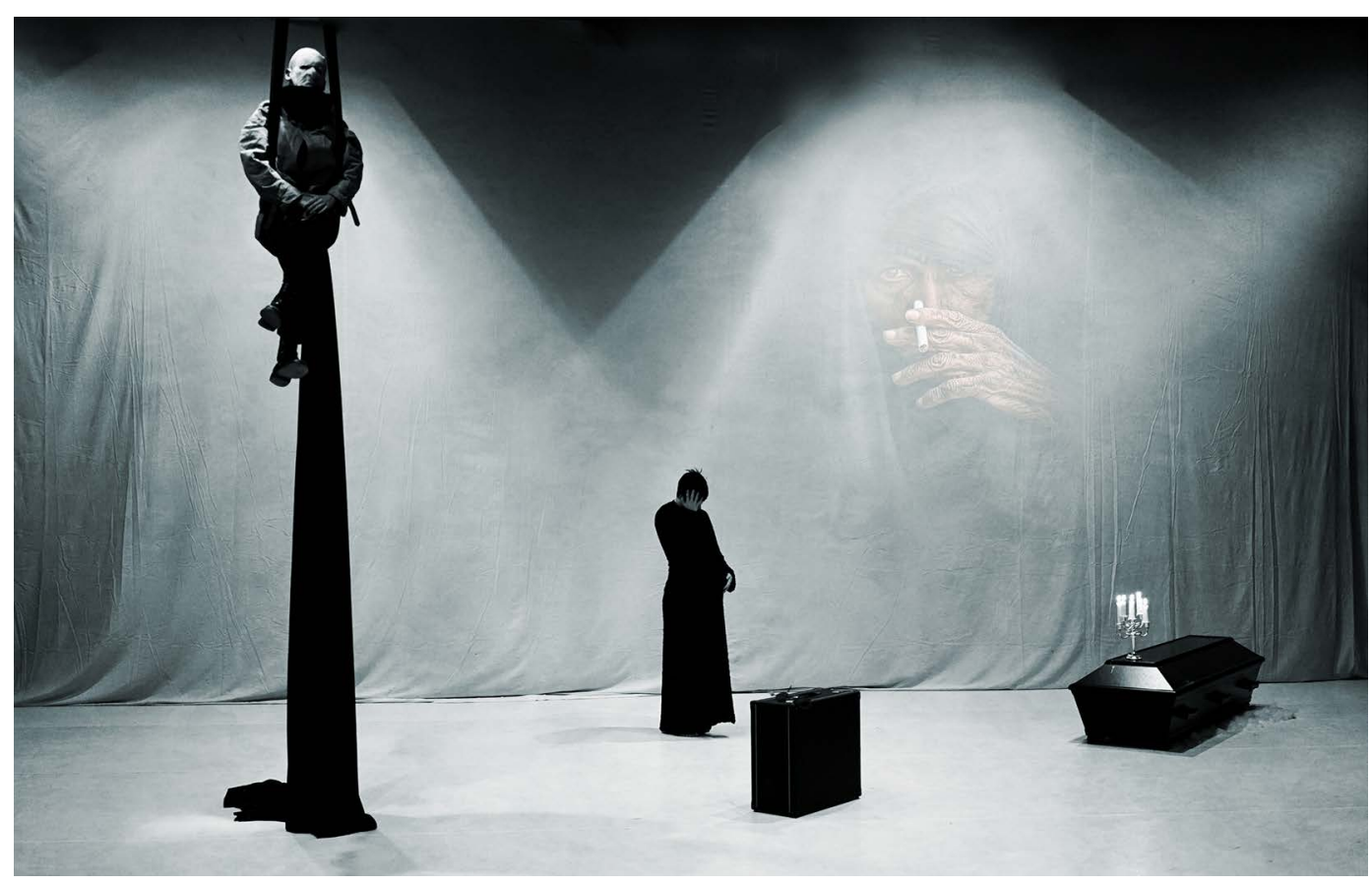

Iraqi Bodies, in Rite of Exile, choreography/performance by Anmar Taha \& Josephine Gray, 2016-17. Photo: Courtesy the artists.

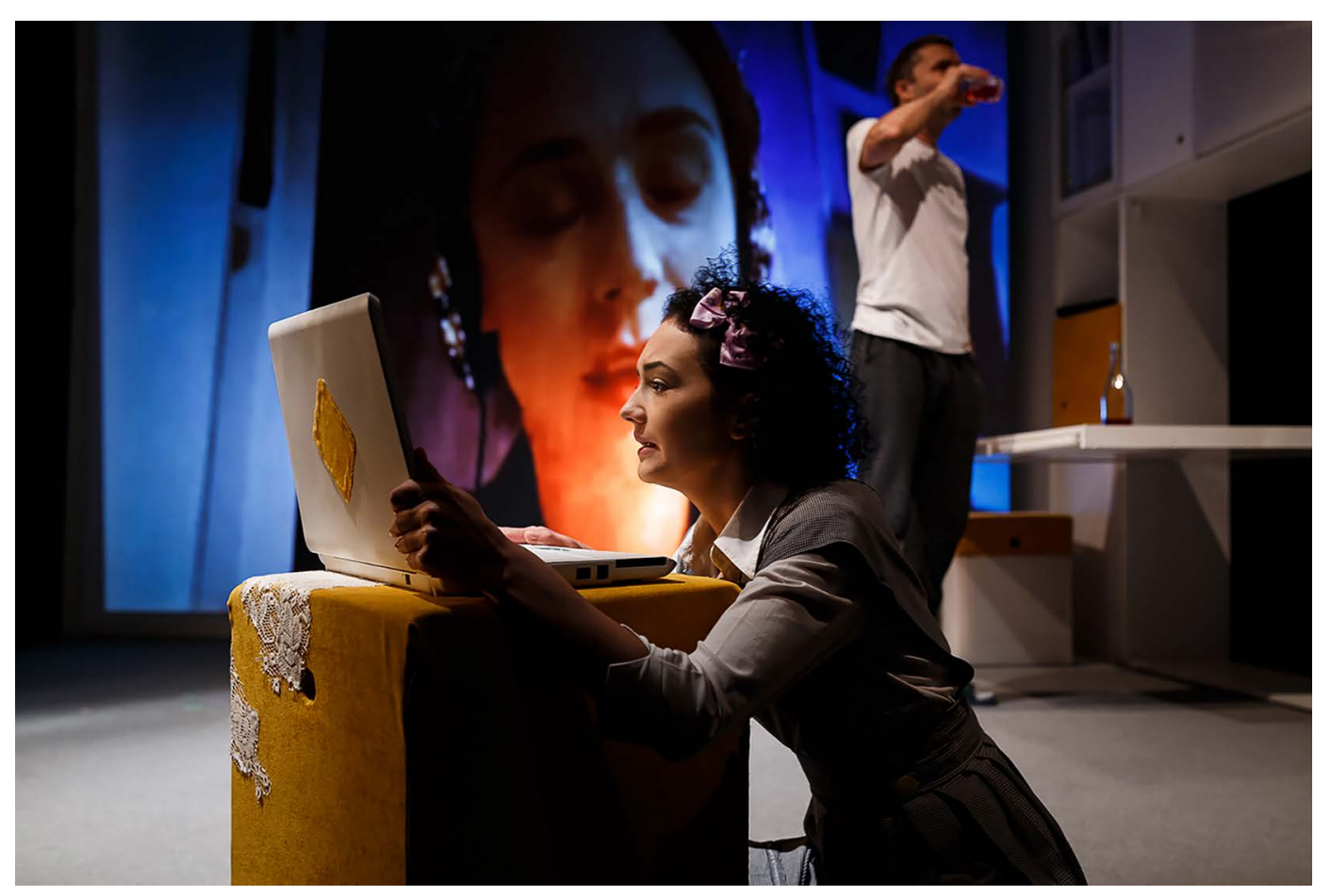

Andreea Darie and Radu Solcanu (downstage) and Ruxandra Oancea (on screen) on the telematic set of Planeta Viselor [The Planet of Lost Dreams]. Multimedia design by Mindscape Studio. 2018. Photo: Courtesy Costin Fetic

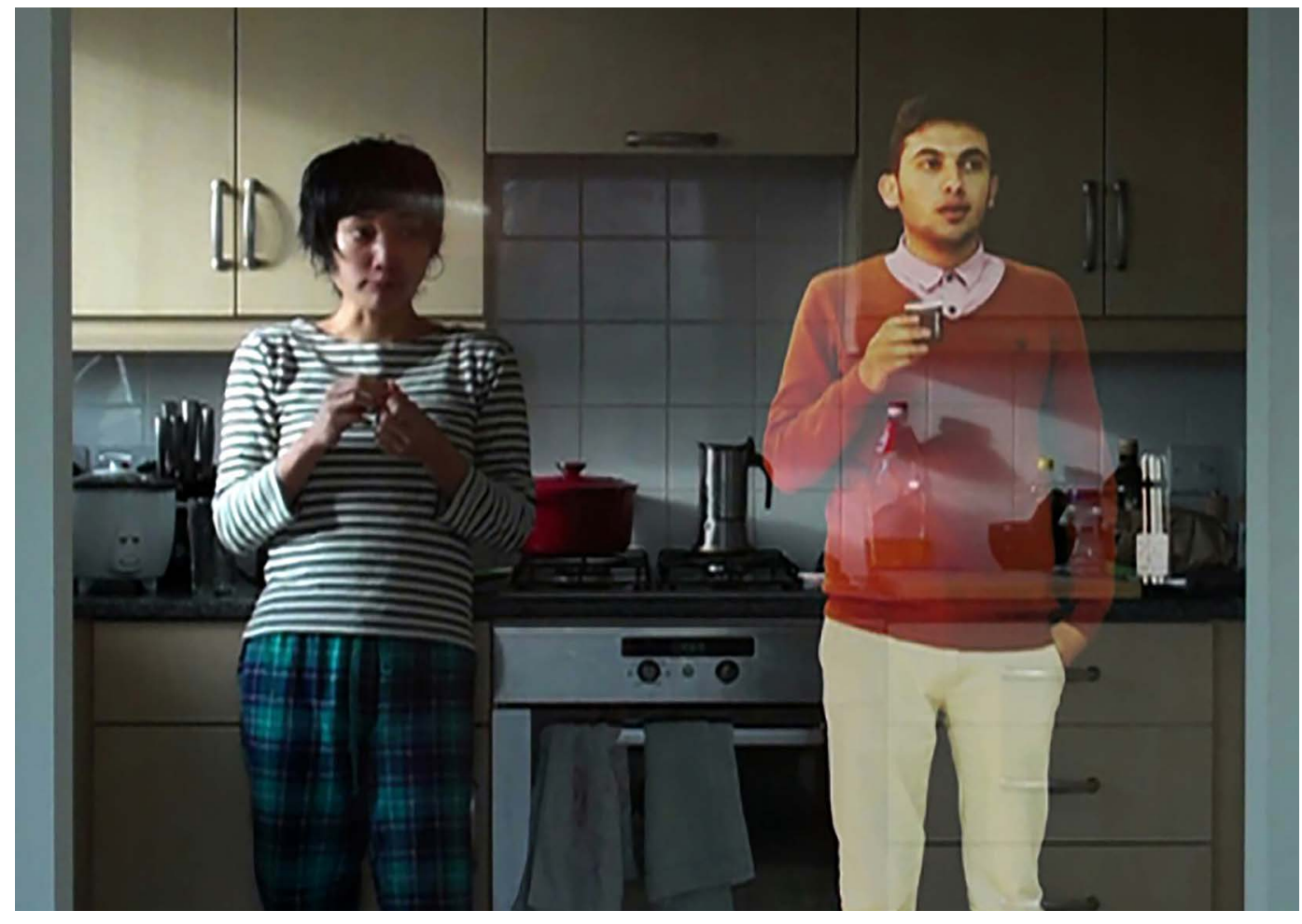

Yoko Ishiguro in London and Ali Hassany, Al-Meshal Theater, Gaza City, during Station House Opera's At Home in Gaza and London, 2016. Photo: Courtesy Station House Opera. 
video-conferencing and Kinect-controlled animation. It premiered live on June 5, 2018, and then had a limited run of seventeen performances through November. During the early run, the directors started collecting written feedback from audiences after each performance, which they analyzed as part of their research on telepresence and migration. Later in the summer they began to livestream the performances with added English subtitles. "Tele-Encounters" continued with further productions: Portuguese partners created five short films in 360 degrees, presented in installations (on VR headsets) in all participating countries. The subject of the films is migration, this time between Spain and Portugal. Late in 2019 the telematic theatre work will segue into dissemination activities in universities/schools (lectures and workshops for students), and Hanganu is publishing a book containing the results of the project.

I draw attention to this since I find fascinating parallels to an undercurrent of social choreographies that deserve greater recognition. They do not necessarily shine on the main stages or festival circuits of our beloved global art world but operate in the fault-lines. "Tele-Encounters" has both an artistic and a sociological dimension, namely the dramatized exploration of relationships between family members separated by migration, conducted through prototypes of telepresence as a structural element in theatre and VR films. The Planet of Lost Dreams is rich in content and invites introspection into how family dynamics and larger societal dynamics within economic relations of dependency are played out (e.g. in the entire service industry sector where many migrant workers, particularly from the former East, have moved to the former West to find employment supporting partners, the elderly, and children back home). The play also quite strikingly sheds light on changing gender dynamics, here dramatizing the troubled fatherdaughter relations in a Romanian family where the worker husband after a job related accident is out of work, depressed and alcoholic, while his wife carries the responsibilities of the bread winner working abroad in Spain. The daughter is torn between protecting and also scolding/resenting her father; she is young and has dreams and expectations, missing her mother while also yearning to visit her abroad, or perhaps choosing a future away from home too.

The question of sustainability and reintegration of family/home vis-à-vis the potential disintegration or diasporic dispersion is raised painfully and left unresolved. Although the emphasis is clearly on economic migration/separation of families and its impact especially on the young, there are painful historical subtexts. Their resonances are varied in the European context, if we think of war-time or postwar refugees and resettlements, cultural exile and displacement, the phenomenon of the Gastarbeiter migration from Greece, Italy, and Turkey up north to Germany during the 1960s, or North Africans moving to France and 
Caribbeans (the Windrush generation) arriving in Britain to settle there. The postcolonial/racial and Cold War ideological contexts loom large, intermixed with the shadow of the past pogroms and expulsions, some of which still unacknowledged (Turkey's denial of the Armenian genocide). In The Planet of Lost Dreams, we also feel the strain placed on more idealistic notions of a common market or union, our eurozone without borders, our common monetary family.

BADco.'s call for necessary reconstructions of institutions is pertinent here. Artistic projects-think of the confrontational "public monument" installations created by Thomas Hirschhorn or the Situation Rooms by Rimini Protokoll-gain significance if they encourage multiplicities of viewpoints. The telematic form of mediatization and live streaming comes as a surprise but, on second thought, makes increasing sense in an era when all generations, particularly the digitally born, communicate with each other through ubiquitous cellular devices and face-time/camera-based exchanges. The two-way telematic stage set is a first challenge: constructing a dramatic and audio-visual spatial coherence that also allows for both linear (telling the story/enacting the physical and psychological consequences of separation/projection and time/place difference) and non-linear cinematic experimentation. The second challenge is the acting on camera. I worry that linear televisual transmission does not easily yield an affective dialectic. The video-conferencing model is constricted by similar or identical sets and camera angles that need to match up, with the video directors either showing us the static rooms in which actors look toward the camera or switching to quasi dynamic facial close ups (actors looking straight at their phones, iPads or webcams). The actors interact with the virtual not-there. This scenario requires a slow space (not Instagrammatic space) to probe and draw out the more imperceptible and intangible misunderstandings: You are over there, and I am over here. We come face to face, connected through camera/network, but our context and life situation may be radically different, and thus I read into your situation as you read into mine. I contextualize you without context.

The main challenge lies in the mediation of the misreadings, and the potential contradictions between narrative and technology. If the directors compose a telematic staging with webcams (and Kinect camera interface for the dream scenes), the augmented reality of this form of theatre can be jarring if realistic acting is mixed with the digital interfaces that tend towards abstraction or technical Verfremdungseffekt (e.g. cartoonish animated digital effects). However, the incongruity of digital abstraction leaking into the old naturalism also offers the potential for poignant reflections on "mediated intimacy," the fragile glue between family members. The seams do not hold well. Yet The Planet of Lost Dreams impressed me with its awareness of the technical dispositif. The modular 
sets in the Romanian and Spanish locations were identical. Camera angles and networked modes of conversation were carefully crafted: the Romanian woman in Murcia (Ruxandra Oancea) leans into the camera, we see her face often, later she grows more distant. Other Spanish actors, such as her fellow workers or her boss, are less present visually, but we hear their voices. Oancea learns Spanish. On the Romanian side we are kept in the spell of the lively and anxious young actress (Andreea Darie) and her emotionally draining relation to her father (Radu Solcanu), her neediness towards her mother whose presence (and bedtime stories) she craves. Solcanu overacted at times, sliding into melodramatic despair and falling for the clichés of wounded toxic masculinity, whereas the young daughter and the daughter-mother relations were more subtly and imaginatively developed.

The dream scenes used newer VR and 3D camera software (such as the Google tilt brush), allowing mother and daughter to flesh out the dreams-drawing them out, so to speak, floating into them. I thought of Saint-Exupéry's Le Petit Prince-the pilot in the desert asked to draw a sheep for the little prince-and the power that fairy tales have on our imagination. Hanganu in fact tried to bring the characters into a shared space on the stage/screen, constructing a theatrical convention beyond theatrical realism. The mother-daughter relationship is at the core of the play, and Hanganu must have imagined a "third space" as a provocative ethical solution, projecting the bond between daughter and mother to transcend relations of austerity and separation. She could have opted to do so by merging the video streams into one image, in the manner in which the London-based Station House Opera company has created their recent productions, to stunning if often grotesque, disorienting effect.

Rather, seeing the young daughter as a child, Hanganu chose the fairy tale aesthetic, closer to the strategy used in Roberto Benigni's La Vita è bella (the way the father presents the horrific reality to his son in the form of a game). In The Planet of Lost Dreams the mother presents the harsh reality to her daughter in the guise of a fairy tale, visually imaged as a sci-fi story with abstracted computer generated silhouettes (produced live through the Kinect camera interface). She tells her daughter that "the poor people" were forced to fly away to other galaxies. They gather there and send fulfilled dreams home to the children they had to leave:

Let me tell you a secret my child

We, the parents wandering on other planets,

And you, the children left behind:

Perhaps we'll succeed one day in transforming

The mother planet into the Planet of Regained Dreams. 
Here narrative and technological strands came together, intimating European countries as foreign planets, avatars of stardust performing intergalactic migrations and reunions.

\section{MORE LOST DREAMS}

This fantasy is held in check by the more oppressive realities that Station House Opera explored in their last transnational project, At Home in Gaza and London (2016). ${ }^{7}$ Their telematic performances were riveting for other reasons, certainly not the linear narrative or any consolation of sci-fi fantasy. At Home in Gaza and London was directed on the London side by Julian Maynard Smith and Taghrid Choucair-Vizoso, and on the Palestine side by Amjad Saeed, with the Station House Opera company generously sharing their expertise in real-time video streaming (having linked performance spaces in theatre productions since the early 2000s). This particular live-streaming performance was a uniquely provocative challenge as the political, cultural, and technical conditions in Gaza and London are so drastically different. For example, domestic religious and external (Israeli) occupying policies made it very hard for the Palestine cast to work during evening hours; Muslim women were restricted from working on line with men in England; the production also had technical breakdowns, as well as language issues (translating Arabic/English during rehearsals and the performance) which made this production most fascinating, as there were also live audiences in both locations invited to interact after the show and comprehend/translate each other's viewpoints. The well-established Station House Opera method is to have identical stage sets and camera angles on either side (using multiple camera feeds). The actors perform improvised dialogues or rehearsed duets: these are blended and dissolved into each other through the video-conferencing software (mixing the two sites). In this instance, a mutual performance space was created for participants in two locations separated by considerable political, economic, and cultural divides. The realities in the occupied territory of Gaza are thus not easily translated at all. This often results in a macabre, ghostly contact improv across the networked space of everyday lives as experienced or imagined. Yoko Ishiguro and Ali Al-Hassany meet in "the kitchen" to have a chat over a cup of coffee. The blending of local and domestic sites from each city implies that such space is or can be shared by both. But I question whether audiences (and actors) on either end can in fact imagine everyday life on the other side.

The real environments are undoubtedly "actors" in the piece, whether they be private rooms in the participants' houses, or the streets in their neighborhoods. Stories are told or enacted, and we watch the eerie superpositions: they are fascinating but also disturbing, since we know they are utterly unreal, the wealth of 
London bears no resemblance to Gaza City. Yet the merging of live video feeds, just as in the case of the side-by-side Planet of Lost Dreams, insinuates that the actors in one city can appear in the spaces of the other. However, they inhabit them only as ghostly presences or avatars. The intimate merger of bodies in the distant participant sites may create new forms of video image, but no political contest. Artistic resilience, however, is directed precisely at the dystopic convention: it resists defeat and authoritarian rule over the freedom to imagine shifts: dislocations of hemispheric (as postulated by Guillermo Gómez-Peña's Aztec Cowboy "Declaration of Poetic Disobedience from the New Border") or PalestineWestern transborder realities. ${ }^{8}$

The carnivalesque chinampa is low-end theory, I fear, on a not very triumphant scale. It is dealing with bottle-caps, found allegories or improvised poetry bearing no real relation to the stakes. ${ }^{9}$ It is small-scale but cannot be underestimated, I argue here, for the love of it, for the pride of resistance. The smaller companies I brought you here may not be so well known, or indeed quite outside of Hito Steyerl's hyperbolic planetary world order, but it does not matter. This low-end theatre has planted seeds, imagining a planet of regained dreams, imagining that there are no walls when we know these injurious border infrastructures exist and are tactical weapons, a form of trauma politics (as I know the U.S.-Mexican border is). In this sense, telematic or (trans)locally reconstructive performances are always also a low-key radical protestation against the status quo (institutions that need to be reconstructed), against the much harsher field causalities. The projects I described offer low threshold views of a kind of forensic architecture, theatres in reverse that love to look our double binds and the multiple scales and durations of violence against law and justice in Europe into the eyes.

\section{NOTES}

1. A provocative approach to caves and brute materials as energy transmitters and mediums is offered by Nicolás Salazar Sutil in Matter Transmission: Mediation in a Paleocyber Age (London: Bloomsbury, 2018), where he examines the mediating qualities of limestone caves (Chauvet, Lascaux, Altamira) in the cultural transmission of Upper Paleolithic imaginaries and memories. His method challenges the late-capitalist extractionist Anthropocene, when he asks: Can we be mediated by earth, and can we understand ourselves as earthlings, common beings interconnected by all-mediating material energies?

2. They showed documentary films and participated in the symposium "Shadows of the Dawn: Migration and the Indeterminacy of Community and Immunity" (Artaud Performance Center, London, April \& June 2018) which I curated at Brunel University. I had met the company at several earlier occasions and also visited them in Zagreb.

3. See Goran Sergej Pristaš, The Exploded Gaze, trans. Žarko Cvejić (Zagreb: Multimedijalni institut, 2018), 201. 
4. For the type of poetry that Taha chooses on occasion as inspiration for his theatre of movement images, see the company's website and, in particular, for the production Body \& Identities: Gerontion: https://www.iraqibodies.com/body--identities-gerontion.

5. Oliver Frljić's production was a spectacular work of performance art that mixed dance, visual choreography, and electronic music collaged into drastic physical theatre scenes intended to shock. The images, including religious symbols and references to rape, torture, terror, fascism, and Islamophobia, evoke an older type of (in yer face) political theatre aesthetic. Frljić, born in Bosnia and now working as artistic director of the Croatian National Theatre of Rijeka, was commissioned by the Berlin HAU Hebbel Theatre/ Wiener Festwochen to devise the performance as an homage to Peter Weiss's Ästhetik des Widerstands. See my "Really Actually Windy: On Environments, Technologies and Dividual Performances," Theatre Journal 68, no. 4 (2016): 633-47.

6. A trailer for The Planet of Lost Dreams is here: https://youtu.be/CojDQE-Vc7M.

7. For a fuller description, see Station House Opera website: www.stationhouseopera .com/project/6246/.

8. See: https://vimeo.com/192179497.

9. Reference to chinampa (floating garden) is owed to Cecil Taylor and Fred Moten's writings: In the Break: The Aesthetics of the Black Radical Tradition (Minneapolis: University of Minnesota Press, 2003). Ghanaian sculptor El Anatsui's exhibition "Triumphant Scale," currently on view at Haus der Kunst in Munich, features immense undulating floating tapestries, along with his bottle-cap works and sculptures made of found plastics and trash associated with consumerism, trade, and ecologies reaching back to slave history (and the import of hard liquors into the African continent). I mention the extraordinary scale of the work here, as it strikes me as a particularly painful irony that the late Okwui Enwezor, a transborder curator who devised this exhibit (at what was originally a show palace during the Nazi era) trying to broaden and diversify viewpoints on contemporary art, but apparently had to struggle to complete it amid distressing reactionary, nativist ideas now taking hold in museums in Germany and Europe.

JOHANNES BIRRINGER is a contributing editor to PAJ and director of the Design and Performance Lab at Brunel University, London. DAP-Lab's most recent dance installations, kimospheres III-V (2016-2018) explore the convergence of physical-sensory and suprasensory/augmented VR spaces. 